\title{
Analisis Pengetahuan tentang Perbankan Syariah Santri Pondok Pesantren Al-Ittihad Mojokerto dan Pengaruhnya terhadap Minat Menabung di Bank Syariah
}

\author{
Tita Octavina Fauzy, Agus Purwadi \& Rahmad Hakim \\ Program Studi Ekonomi Syariah, Fakultas Agama Islam, \\ Universitas Muhammadiyah Malang \\ Email: titafauzy97@gmail.com, \\ agpurwo_adi@yahoo.co.id, \\ rahmadhakim@umm.ac.id
}

\begin{abstract}
This study aims to determine the correlation between the knowledge owned by students of Al-Ittihad Mojokerto Islamic boarding school to the interest in saving in Islamic banking. This study is a quantitative and the data collection method used questionnaires. The results of this study, the significance value of the variable students' knowledge was equal to $.000<.05$ and there was a positive influence between the variable of knowledge of students about Islamic banking $(\mathrm{X})$ towards the interest in saving in Islamic banking $(\mathrm{Y})$. Therefore, Ho is rejected and $\mathrm{Ha}$ is accepted. Moreover, the result of $r_{-}$(count) is .753 greater than $r_{-}$(table), which is equal to .195 . According to the criteria, the relationship between the dependent and independent variables showed a strong and significant correlation between the variable knowledge of students and interest in saving. Moreover, the knowledge was
\end{abstract}


greater so, the interest of saving also was greater. It was expected for further research, in order to increase the number of respondents and variables. The results of further research can be further elaborated.

Keywords: Students' Knowledge, Saving, Islamic Bank.

\section{Pendahuluan}

Secara umum, santri pondok pesantren sebagian besar berasal dari berbagai daerah, yang mana kebanyakan dari santrisantri tersebut berasal dari luar Kota maupun luar Jawa. Di pondok pesantren mereka juga mempelajari tentang agama, salah satu yang mereka pelajari sedikit banyak adalah tentang ekonomi Islam. Seperti, bagaimana cara bertransaksi yang benar menurut Islam, syarat-syarat jual beli, tentang kegiatan bertransaksi dengan menggunakan prinsip-prinsip ekonomi Islam. Menurut penjelasan di atas, maka dari itu santri pondok pesantren sedikit banyak pasti

pernah mendengar mengenai bank syariah, ataupun pernah bertransaksi dengan menggunakan bank syariah maupun bank konvensional untuk kepentingan pribadi mereka. Apalagi mereka jauh dari kedua orangtua sehingga transaksi melalui jasa keuangan perbankan sangat dibutuhkan.

Perbankan syariah merupakan segala sesuatu yang berhubungan dengan bank syariah, dan unit usaha syariah lainnya. 
Baik dalam proses bertransaksi, kegiatan usaha, prinsip-prinsip syariah yang digunakan dalam proses melakukan kegiatan usahanya. Sedangkan bank syariah dapat juga diartikan sebagai lembaga keuangan bank yang mendorong dan mengajak masyarakat untuk ikut serta dalam bertransaksi menggunakan produk-produknya, sedangkan disisi aktiva atau disisi asset bank syariah mulai aktif untuk berinvestasi pada masyarakat. ${ }^{1}$ Secara umum bank syariah dapat diartikan sebagai bank dengan sistem mudhorobah atau bagi hasil yang dijadikan sebagai landasan utama segala bentuk transaksinya, baik dalam produk pembiayaan, tabungan maupun dalam produk lainnya. ${ }^{2}$

Perkembangan bank syariah di Indonesia saat ini sangat pesat jika dibandingkan dengan bank konvensional. Hal ini dapat dibuktikan dengan munculnya berbagai macam bank syariah yang ada di Indonesia, mulai dari bank BRI Syariah, bank BNI Syariah, Mandiri Syariah dan lain sebagainya. Dan total kenaikan asset pada perbankan syariah meningkat dari $0,03 \%$ menjadi 5,20\% peningkatan pangsa pasar ini dipengaruhi oleh pertumbuhan asset bank syariah sebesar 2,28\% dan peningkatan ini lebih tinggi dari bank konvensional yaitu sebesar $1,80 \%{ }^{3} \quad$ Namun, meskipun bank

\footnotetext{
${ }^{1}$ Gita Danupranata, Manajemen Perbankan Syariah, Jakarta: Salemba Empat, 2013), 31

2 Ascarya. Akad Dan Produk Bank Syariah. (Jakarta: Gramedia, 2007), 1 ${ }^{3}$ www.OJK.go.id di akses pada 16 Februari 2019, pkl. 08.42
} 
syariah di Indonesia sudah cukup banyak akan tetapi asset dari perbankan syariah masih tertinggal dengan asset yang dimiliki oleh bank konvensional, sehingga bank syariah saat ini masih di tuntut untuk bersaing dengan bank konvensional.

Salah satu faktor mendasar yang dapat mengembangkan perbankan syariah dikalangan santri adalah dengan pengetahuan. Pengetahuan adalah segala sesuatu yang ada dikepala kita. ${ }^{4}$ Menurut kamus besar bahasa Indonesia pengetahuan yakni segala sesuatu yang diketahui, kepandaian. Maka dari itu di sinilah peran perbankan syariah untuk mulai memberikan pengetahuan kepada santri tentang sistem transaksi yang ada di perbankan syariah, mulai dari prinsipprinsip yang digunakan dalam melakukan transaksi, produk-produk yang ada di bank syariah, perbedaan sistem operasional antara bank syariah dan bank konvensional.

Penelitian ini akan mengambil sampel pada pondok pesantren Al-Ittihad Mojokerto, karena pondok pesantren AlIttihad Mojokerto menurut saya mempunyai nilai tambah jika dibandingkan dengan pondok pesantren lainnya, karena pondok pesantren ini sangat menonjolkan nilai agama dan nilai akademis, selain itu disekitar pondok pesantren ini juga terdapat berbagai macam bank syariah di antaranya yaitu, BRI Syariah, Bank Syariah Mandiri, BNI Syariah, BCA Syariah.

\footnotetext{
4 Bambang Prasetyo dan Lina Miftahul Jannah, Metode Penelitian Kuantitatfif, Teori dan Aplikasi, (Jakarta: PT Raja Grafindo Persada, 2006), 3
}

184 Vol. 4, No. 2, September 2019 
Pada penelitian terdahulu, Penelitian yang dilakukan oleh Arifatul Aini menjelaskan bahwa variabel pengetahuan masyarakat memiliki pengaruh yang positif dan signifikan terhadap minat menjadi nasabah yaitu sebesar 0,001 dibawah 0,05 . Hal ini berarti pengetahuan masyarakat terhadap minat menabung di bank sangat penting dan diperlukan ${ }^{5}$. Keterbatasan dalam penelitian ini yaitu penelitian ini menggunakan kuisioner melalui google docs, sehinnga tidak bisa bertatapan langsung dengan responden, dan tidak semua responden mampu untuk menggunakan google docs.

Penelitian yang dilakukan oleh Aditya Abdi menyatakan bahwa pengetahuan konsumen dapat mempengaruhi keputusan menjadi nasabah pada Bank Syariah Mandiri Bondowoso. Kelemahan dalam penelitian ini yaitu menggunakan rumus yang cukup rumit dan susah untuk dimengerti. ${ }^{6}$ Selanjutnya, penelitian yang dilakukan oleh Hendrik Saputra menjelaskan bahwa mahasiswa program studi non ekonomi Islam memiliki persepsi yang positif atau baik tentang ekonomi Islam dan mahasiswa tersebut juga memiliki keingininan untuk menabung di bank syariah tersebut.

\footnotetext{
${ }^{5}$ Arifatul Aini, Pengarub Pengetabuan Masyarakat Terbadap Minat Menjadi Nasabah Bank Muamalat Cabang Kendal (Studi Pada Masyarakat Kecamatan Kota Kendal, Kabupaten Kendal). (Skripsi Fakultas Ekonomi dan Bisnis Universitas Islam Negri Walisongo, Semarang 2014), 54

${ }^{6}$ Aditya Abdi, "Pengarub Pengetabuan tentang Perbankan Syariah terbadap Minat Menjadi Nasabah pada PT Bank Mandiri Syariah Mandiri Tbk, Cabang Bondowoso", (Skripsi Fakultas Ekonomi dan Bisnis Universitas Negri Jember, Jember 2014), 63
} 
Persepsi mahasiswa program studi non ekonomi Islam berpengaruh secara signifikan terhadap minat menjadi nasabah di bank syariah ${ }^{7}$. Kelemahan dalam penelitian ini adalah adanya mahasiswa yang beragama non Islam yang tidak tahu tentang konsep ekonomi Islam, sehingga hal ini menyulitkan peneliti untuk mencari responden.

Penelitian yang dilakukan oleh Raifana Faras, tentang pengaruh pengetahuan tentang Riba terhadap minat mahasiswa Universitas Islam Indonesia untuk menjadi nasabah di Bank Syariah, menyimpulkan bahwa tingkat signifikansi mencapai nilai 0,002 dengan demikian bahwa terdapat hubungan yang erat variable $\mathrm{x}$ dan y. Maka, minat mahasiswa Universitas Islam Indonesia untuk menjadi nasabah bank syariah dipengaruhi oleh pengetahuan tentang riba ${ }^{8}$. Keterbatasan dalam penelitian ini adalah adanya mahasiswa yang hanya memikirkan keuntungan dan tidak memperdulikan adanya konsep riba.

Oleh karena itu penelitian ini bertujuan untuk mengetahui seberapa besar pengaruh pengetahuan yang dimiliki oleh santri terhadap minat menabung di bank syariah dan karena perkembangan perbankan syariah pada saat ini yang mulai meluas,

7 Hendrik Saputra. 2019. "Pengaruh Persepsi Mahasiswa Program Studi Non Ekonomi Islam tehadap Minat menjadi Nasabah di Bank Syariab”. Vol. 2, No. 1. 67-76

${ }^{8}$ Raifana Faras. Pengarub Pengetahuan Tentang Riba Terbadap Minat Mahasiswa Universitas Islam Indonesia Untuk Menjadi Nasabah Di Bank Syariab. (Skripsi Fakultas Ekonomi Universitas Islam Indonesia, Yogyakarta 2014), 43

186 Vol. 4, No. 2, September 2019 
yaitu dengan memberikan pengetahuan lebih kepada lembagalembaga pendidikan Islam untuk mulai menabung di bank syariah.

\section{Landasan Teori}

\subsection{Definisi dan Tingkatan Pengetahuan}

Menurut Bloom, Pengetahuan adalah hasil keingintahuan, segala perbuatan atau usaha manusia untuk memahami obyek yang dihadapinya. Pengetahuan dapat berwujud barang-barang fisik yang pemahamannya dilakukan dengan cara persepsi, baik melalui panca indera maupun akal ${ }^{9}$. Menurut kamus besar bahasa Indonesia pengetahuan adalah segala sesuatu yang diketahui kepandaian yang berhubungan dengan suatu hal ${ }^{10}$. Pengetahuan merupakan hasil mengingat suatu hal, termasuk mengingat kembali kejadian yang pernah dialami baik secara sengaja maupun tidak disengaja dan ini terjadi setelah orang melakukan atau pengamatan terhadap suatu obyek tertentu. Pengetahuan konsumen juga dapat diartikan sebagai semua informasi yang dimiliki konsumen mengenai berbagai macam produk dan jasa, serta informasi yang berhubungan dengan fungsi sebagai konsumen. Terdapat beberapa tingkatan didalam

\footnotetext{
${ }^{9}$ I Made Wirartha. Metodologi Penelitian Sosial Ekonomi. (Yogyakarta: ANDI. 2006), 1

10 Tim Redaksi. Kamus Besar Bahasa Indonesia Pusat Bahasa. Ed. 4. (Jakarta: PT. Gramedia Pustaka Utama. 2008), 1.377
}

Iqtishodia : Jurnal Ekonomi Syariah 
pengetahuan, yaitu ${ }^{11}$ : (1) tahu (know), merupakan pengetahuan paling rendah, dapat diartikan sebagai mengingat suatu materi yang telah dipelajarinya. (2) memahami (comprehension), artinya suatu kemampuan untuk menjelaskan secara benar tentang apa yang diketahui sehingga orang yang paham terhadap suatu materi dapat menjelaskan, menyebutkan contoh atau menyimpulkan objek yang dipelajari. (3) aplikasi (application), merupakan kemampuan untuk menggunakan materi yang telah dipelajari pada situasi dan kondisi, seperti penggunaan hukum-hukum, rumus, prinsip dan lain sebagainya. (4) analisis (analysis), merupakan suatu kemampuan untuk menyatakan materi dalam komponen-komponen tetapi masih ada kaitannya satu sama lain. (5) sintesis (syntesis), merupakan suatu kemampuan untuk menghubungkan bagian-bagian dalam suatu formulasi yang baru. (6) evaluasi (evaluation ), merupakan kemampuan untuk melakukan penilaian terhadap materi berdasarkan kriteria yang ditentukan sendiri maupun menggunakan kriteria yang sudah ada.

\subsection{Faktor-Faktor yang Mempengaruhi}

\section{Pengetahuan}

11 Wawan, Dewi, Teori dan Pengukuran Pengetabuan, Sikap, dan Perilaku Manusia, (Yogyakarta: Nusa Medika, 2011), 13

188 Vol. 4, No. 2, September 2019 
Adapun beberapa faktor-faktor yang mempengaruhi pengetahuan seseorang yaitu, pendidikan, pengalaman, dan usia. Berikut adalah penjelasan faktor-faktor tersebut:

a. Pendidikan

Tingkat pendidikan turut menentukan mudah tidaknya seseorang menyerap dan memahami pengetahuan yang mereka peroleh, pada umumnya semakin tinggi pendidikan seseorang maka semakin baik pula pengetahuannya.

b. Pengalaman

Pengalaman merupakan sumber pengetahuan atau pengalaman itu suatu cara untuk memperoleh kebenaran pengetahuan. Maka, pengalaman pribadi dapat digunakan sebagi upaya untuk memperoleh pengetahuan. Hal ini dilakukan dengan cara mengulang kembali pengalaman yang diperoleh dalam memecahkan permasalahan yang dihadapi.

c. Usia

Semakin bertambahnya usia seseorang maka proses-proses perkembangan metalnya akan bertambah baik, akan tetapi pada umur tertentu, bertambahnya proses perkembangan mental ini tidak secepat seperti ketika berumur belasan tahun.

d. Informasi

Informasi akan memberikan pengetahuan bagi seseorang. Meskipun seseorang memiliki pendidikan yang rendah tetapi jika ia mendapatkan informasi yang baik dari berbagai media dan berbagai 
macam kegiatan yang ia ikuti, maka hal itu akan dapat meningkatkan pengetahuan seseorang.

e. Hubungan Sosial

Faktor hubungan sosial mempengaruhi kemampuan individu untuk melakukan hal serupa. Apabila hubungan sosial seseorang dengan individu baik maka pengetahuan yang dimiliki juga akan bertambah.

Dalam perspektif yang beragam pengetahuan dapat dilihat dari berbagai perspektif yaitu ${ }^{12}$ :

a. Pengetahuan sebagai sebuah kondisi pikiran

Pengetahuan telah banyak dilukiskan sebagai kondisi atau fakta dari mengetahui. Pandangan tentang pengetahuan sebagai kondisi dari pikiran menitik beratkan kemampuan individu untuk mengembangkan pengetahuan personal mereka dan mengaplikasikan pengetahuan tersebut sesuai dengan kebutuhan.

b. Pengetahuan sebagai sebuah objek

Pengetahuan juga sering dipandang sebagai objek. Pandangan ini menyatakan bahwa pengetahuan merupakan suatu yang dapat disimpan dan di manipulasi (misalnya objek).

12 Nurul Indarti, Manajemen Pengetabuan: Teori dan Praktik, (Yogyakarta: Gadjah Mada University Press, 2014), 14

190 Vol. 4, No. 2, September 2019 
Pengetahuan dapat disimpan dalam catatan-catatan, buku, CD, dan dokumen-dokumen lainnya.

c. Pengetahuan sebagai sebuah proses

Pandangan ini menitik beratkan pada aplikasi pengetahuan. Dengan pengetahuan yang dimiliki, seseorang akan melakukan tindakan berdasarkan pengetahuan tersebut.

d. Pengetahuan sebagai kondisi untuk mendapatkan pengetahuan

Dalam hal ini melihat bahwa pengetahuan sebagai sebuah kondisi untuk mengakses informasi-informasi yang ada

e. Pengetahuan sebagai sebuah kapasitas

Pengetahuan dapat diartikan sebagai kemampuan yang secara potensial dapat mempengaruhi tindakan di masa datang. Tidak hanya sebatas kemampuan seputar tindakan tertentu, tetapi juga kemampuan untuk menggunakan informasi, pembelajaran, dan pengalaman yang menghasilkan kemampuan untuk mengintepretasi dan menemukan informasi yang dibutuhkan dalam pengambilan keputusan.

2.3. Minat 
Dalam ensiklopedia umum disebutkan bahwa minat adalah kecenderungan bertingkah laku yang terarah pada obyek kegiatan atau pengalaman tertentu ${ }^{13}$.

Dilihat dari segi bahasa minat adalah "kecenderungan hati yang tinggi terhadap sesuatu, gairah, keinginan" ${ }^{14}$. Minat adalah suatu perangkat mental yang terdiri dari suatu campuran dari perasaan, harapan, pendirian, prasangka, rasa takut atau kecenderungan-kecenderungan lain yang mengarahkan individu kepada suatu pilihan tertentu ${ }^{15}$.

\section{Faktor - Faktor yang Mempengaruhi Minat}

Menurut Crow faktor-faktor yang mempengaruhi minat, antara lain ${ }^{16}$ :

a. Dorongan dari dalam individu

Misalnya, dorongan untuk makan. Dorongan untuk makan akan membangkitkan minat untuk bekerja atau mencari penghasilan, minat terhadap produksi makanan dan lain-lain.

b. Motif Sosial 2.252

${ }^{13}$ Hasan Shadily. Ensiklopedia umum. (Jakarta: ichtia barn van hoeve. 1983),

${ }^{14}$ Kamus Besar Bahasa Indonesia, (Jakarta:Balai Pustaka, 1990), 178

15 Andi Mapiare, Psikologi remaja. (Surabaya: Usaha Nasional, 1982) , 82

16 Sukamto, Nafsiologi, (Jakarta: Integritas Press, 1985), 120

192 Vol. 4, No. 2, September 2019 
Minat yang datang dari lingkungan sekitar tetangga, teman, saudara. Faktor ini dapat menjadi faktor yang membangkitkan minat untuk melakukan aktivitas tertentu.

c. Faktor Emosional

Minat mempunyai hubungan yang erat dengan emosi, yaitu keinginan sesaat. Dengan demikian maka dapat disimpulkan bahwa minat adalah dorongan kuat bagi sesseorang untuk melakukan segala sesuatu dalam mewujudkn pencapaian tujuan dan cita-cita keinginannya. Selain itu, minat dapat timbul karena adanya faktor eksternal dan juga adanya faktor internal.

\subsection{Bank Syariah}

Bank adalah suatu lembaga keuangan yang memberikan jasa berupa memberikan kredit dan jasa-jasa dalam bidang pembayaran dan peredaran uang. Selain itu bank juga dapat diartikan sebagai suatu badan usaha yang menghimpun dana dari masyarakat dalam bentuk simpanan dan menyalurkannya kepada masyarakat kembali 
dalam bentuk kredit dan bentuk-bentuk lainnya dalam rangka menaikkan taraf hidup masyarakat ${ }^{17}$.

Sebagai badan usaha yang bergerak dibidang keuangan bank juga akan selalu berusaha mendapatkan keuntungan yang sebesar besarnya dari usaha yang dijalankannya. Sebaliknya, sebagai lembaga keuangan, bank juga mempunyai kewajiban pokok untuk menjaga kestabilan nilai uang atau likuiditas, perluasan lapangan kerja, dan mendorong kegiatan ekonomi.

\section{Pengetahuan tentang Perbankan Syariah Santri Pondok Pesantren Al-Ittihad Mojokerto dan Pengaruhnya terhadap Minat Menabung di Bank Syariah}

\section{Profil Singkat Pondok Pesantren Al-Ittihad Mojokerto}

Pondok pesantren Al - Ittihad Mojokerto berdiri pada tahun 1956, pondok pesantren ini berada di kabupaten Mojokerto yang lokasinya tidak jauh dari pusat kota Mojokerto. Didirikan oleh KH. Nawawi Romli, beliau anak ke tiga dari 9 bersaudara. KH. Nawawi Ramli menikah dengan Hj. Marhamah dan memiliki 6 anak, yaitu: Muhayyah Mas'ud, Masrukhan, Masduki, Al-Bazi, dan Abdul Qadir. Setelah Hj. Marhamah wafat beliau menikah dengan $\mathrm{Hj}$. Shalihah, ia seorang janda dan memiliki 1 anak yaitu $\mathrm{H}$. Abd.

17 Rachmadi Usman, Aspek-Aspek Hukum Perbankan Di Indonesia, (Jakarta: Gramedia, 2001), 39

194 Vol. 4, No. 2, September 2019 
Qodim. Setelah menikah dengan $\mathrm{Hj}$. Sholihah, beliau berinisiatif untuk mendirikan Pondok pesantren ini karena ingin mengajak masyarakat khususnya masyarakat Mojokerto agar lebih mendalami agama Islam dan karena semakin bertambah nya jumlah jamaah majelis ta'lim tartil Al-Quran yang mengikuti.

Pada tahun 1966 pondok pesantren ini mulai berkembang pesat dengan semakin bertambahnya jumlah santri yang ada. Santrisantri tersebut tidak hanya santri yang ingin menghafal Al-Qur'an akan tetapi santri yang juga ingin memperdalam agama Islam melalui kitab-kitab yang diajarkan juga diterima di pondok pesantren ini. Santri-santri tersebut mempunyai usia yang berbeda-beda antara usia 12 tahun hingga 40 tahun. Karena semakin bertambahnya jumlah santri, maka pada tahun 1967 pondok pesantren ini dibangun dan menjadi semakin luas. Selain itu, mengingat semakin bertambahnya santri dan dari berbagai usia, pondok pesantren ini semakin berkembang dengan menggabungkan pendidikan klasikal dan pendidikan modern. Yakni, mulai dari PAUD Al-Ittihad, RA Al-Ittihad, MI Al-Ittihad, SMP Al-Ittihad, dan MA Al-Ittihad. Semua itu berdiri di dalam satu yayasan yaitu yayasan pendidikan dan sosial Al-Ittihad. Setelah KH. Nawawi wafat, maka pondok pesantren Al-Ittihad ini dikelola oleh putra KH. Nawawi yang ke lima, yaitu KH. Al-Bazi Nawawi hingga saat ini. Dan pada tahun 2014 pondok pesantren Al-Ittihad mulai menerima santri putri. 


\section{Analisis Pengaruh Pengetahuan}

Dalam penelitian ini menggunakan Uji Validitas, Uji Reliabilitas dan Uji Korelasi. Uji validitas dalam penelitian ini menggunakan tingkat signifikansi $5 \%$ atau 0,05 dan jumlah responden yang diambil sebesar 100 orang, sehingga didapatkan nilai $r_{\text {tabel }}$ sebesar 0,195 . Berikut hasil uji validitas

Tabel 1.1

Uji Validitas

\begin{tabular}{|c|c|c|c|c|}
\hline Variabel & Butir & $r_{\text {hitung }}$ & $r_{\text {tabel }}$ & Keterangan \\
\hline Pengetahuan & 1 & 0,426 & 0,195 & Valid \\
(X) & 2 & 0,547 & 0,195 & Valid \\
& 3 & 0,425 & 0,195 & Valid \\
& 4 & 0,536 & 0,195 & Valid \\
& 5 & 0,557 & 0,195 & Valid \\
& 7 & 0,545 & 0,195 & Valid \\
& 8 & 0,407 & 0,195 & Valid \\
& 9 & 0,557 & 0,195 & Valid \\
& 10 & 0,495 & 0,195 & Valid \\
& 11 & 0,532 & 0,195 & Valid \\
\hline
\end{tabular}

196 Vol. 4, No. 2, September 2019 


\begin{tabular}{|l|c|c|c|c|}
\hline Minat (Y) & 1 & 0,419 & 0,195 & Valid \\
& 2 & 0,633 & 0,195 & Valid \\
& 3 & 0,361 & 0,195 & Valid \\
4 & 0,490 & 0,195 & Valid \\
& 5 & 0,716 & 0,195 & Valid \\
& 6 & 0,388 & 0,195 & Valid \\
& 7 & 0,332 & 0,195 & Valid \\
& 8 & 0,606 & 0,195 & Valid \\
& 9 & 0,372 & 0,195 & Valid \\
& 10 & 0,401 & 0,195 & Valid \\
& 11 & 0,516 & 0,195 & Valid \\
\hline
\end{tabular}

Hasil uji validitas pada tabel 1.1 dapat dilihat bahwa masingmasing pernyataan dari variabel pengetahuan santri tentang perbankan syariah dan variabel minat menabung mempunyai kriteria valid untuk semua item pertanyaan dengan nilai signifikansi lebih besar dari $r_{\text {tabel }}$ yaitu sebesar $5 \%$. Sehingga dapat dikatakan item pernyataan yang digunakan dalam penelitian ini layak dan valid digunakan sebagai pengumpulan data.

Kriteria pengambilan keputusan dalam pengujian reliabilitas adalah apabila hasil pengujian reliabilitas untuk variabel $\mathrm{X}$ 
pengetahuan santri dan variabel $Y$ minat menabung dengan batasanbatasan reliabilitas yang telah ditentukan sebagai berikut:

- Nilai Alpha Cronbach 0,00-0,20 : Kurang reliabel

- Nilai Alpha Cronbach 0,21-0,40 : Agak reliabel

- $\quad$ Nilai Alpha Cronbach 0,41 - 0,60 : Cukup reliabel

- $\quad$ Nilai Alpha Cronbach 0,61 - 0,80 : Reliabel

- $\quad$ Nilai Alpha Cronbach 0,81-1,00 : Sangat reliabel

Tabel 1.2

Uji Reliabilitas

\begin{tabular}{|c|c|c|}
\hline Variabel & Cronbac'h Alpha & Keterangan \\
\hline Pengetahuan $(\mathrm{X})$ & 0,705 & Reliabel \\
\hline Minat menabung $(\mathrm{Y})$ & 0,666 & Reliabel \\
\hline
\end{tabular}

Hasil pengujian reliabilitas pada tabel 1.2 menunjukkan bahwa nilai Cronbac'b Alpha pada variabel pengetahuan sebesar 0,705 dan variabel minat sebesar 0,666. Masing-masing lebih besar dari 0,60 maka dapat dikatakan bahwa item pernyataan yang digunakan dalam penelitian ini sudah reliabel dan dapat digunakan untuk penelitian selanjutnya.

Analisis korelasi digunakan untuk mengetahui derajat hubungan linier antara satu variabel dengan variabel yang lain. Kriteria pengujian dan kriteria tingkat korelasi sebagai berikut: 
Kriteria pengujian apabila:

- $\mathrm{r}_{\text {hitung }}>\mathrm{r}_{\text {tabel }}$ maka $\mathrm{H}_{\mathrm{o}}$ ditolak

- $\mathrm{r}_{\text {hitung }}<\mathrm{r}_{\text {tabel }}$ maka $\mathrm{H}_{\mathrm{o}}$ diterima

Tingkat korelasi dan kekuatan hubungan:

$0,00-0,29 \quad$ : Korelasi sangat lemah

$0,30-0,49 \quad$ : Korelasi lemah

0,50-0,69 : Korelasi cukup

$0,70-0,79 \quad$ : Korelasi kuat

$0,80-1,00 \quad$ : Korelasi sangat kuat

\section{Perhitungan manual nilai $\mathbf{r}$}

Diket :

$$
\begin{array}{lc}
\mathrm{n} & : 100 \\
\sum X Y & : 216.955 \\
\sum X & : 4.678 \\
\sum Y & : 4.615 \\
\sum X^{2} & : 220.316 \\
\sum Y^{2} & : 214.337 \\
r_{\text {hitung }}=\frac{n\left(\sum X Y\right)-\left(\sum X\right)\left(\sum Y\right)}{\sqrt{\left[n\left(\sum X^{2}\right)-\left(\sum X\right)^{2}\right]\left[n\left(\sum Y^{2}\right)-\left(\sum Y\right)^{2}\right]}} \\
=\frac{100(216.955)-(4.678)(4.615)}{\sqrt{[100(220.316)-(21.883 .684)][100(214.337)-(21.298 .225)]}}
\end{array}
$$




$$
\begin{gathered}
=\frac{(21.695 .500)-(21.558 .970)}{\sqrt{(147.916)(135.475)}} \\
=\frac{106.530}{\sqrt{20.038 .920 .100}} \\
r_{\text {hitung }}=0,7525 \longrightarrow \\
r_{\text {tabel }} \longrightarrow \quad 0,753 \\
\mathrm{Db}=5 \%(0,05) \\
=\mathrm{N}-2 \\
=100-2=98
\end{gathered}
$$

\begin{tabular}{|c|c|c|c|c|}
\hline \multicolumn{5}{|c|}{ Correlations } \\
\hline & & $\mathrm{X}$ & $\mathrm{Y}$ & \\
\hline \multirow[t]{3}{*}{$\mathrm{X}$} & Pearson Correlation & 1 & & $.753^{* *}$ \\
\hline & Sig. (2-tailed) & & & .000 \\
\hline & $\mathrm{N}$ & 100 & & 100 \\
\hline \multirow[t]{3}{*}{ Y } & Pearson Correlation & $.753^{* *}$ & & 1 \\
\hline & Sig. (2-tailed) & .000 & & \\
\hline & $\mathrm{N}$ & 100 & & 100 \\
\hline
\end{tabular}

\section{Tabel 1.3}

Uji Korelasi

Berdasarkan perhitungan manual dan SPSS hasil analisis korelasi yang telah dilakukan oleh peneliti bahwa $\mathrm{r}$ antara 2 variabel 200 Vol. 4, No. 2, September 2019 
yaitu variabel pengetahuan dan minat sebesar 0,753 lebih besar dari nilai $r_{\text {tabel }}$ sebesar 0,195. Menurut kriteria keeratan hubungan antara variabel dependen dan independen menunjukkan adanya hubungan yang kuat dan bentuk hubungannya positif. Berdasarkan hasil di atas nilai signifikansi sebesar 0,00 yang berarti kurang dari 0,05, maka hipotesis nol (Ho) di tolak dan Ha diterima. Maka dapat di simpulkan bahwa terdapat hubungan kuat antara variabel pengetahuan dan minat serta keduanya signifikan.

Tabel 1.4.

Uji T

\begin{tabular}{|c|c|c|c|c|c|}
\hline \multicolumn{6}{|c|}{ Coefficients $^{a}$} \\
\hline \multirow[b]{2}{*}{ Model } & \multicolumn{2}{|c|}{ Unstandardized Coefficients } & \multirow{2}{*}{$\begin{array}{c}\text { Standardized } \\
\text { Coefficients } \\
\text { Beta } \\
\end{array}$} & \multirow[b]{2}{*}{$\mathrm{T}$} & \multirow[b]{2}{*}{ Sig. } \\
\hline & B & Std. Error & & & \\
\hline 1 (Constant) & 12.459 & 2.988 & & 4.169 & .000 \\
\hline $\mathrm{X}$ & .720 & .064 & .753 & 11.313 & .000 \\
\hline
\end{tabular}

Variabel pengetahuan santri terhadap minat menabung menunjukkan bahwa nilai uji korelasi $r_{\text {hitung }}$ sebesar 0,753 dan $r_{\text {tabel }}$ sebesar 0,195 maka $r_{\text {hitunng }}>r_{\text {tabel }}$ hal ini berarti adanya hubungan yang kuat dan bentuk hubungannya positif. Berdasarkan 
hasil di atas nilai signifikansi sebesar $0,00<0,05$, maka hipotesis nol (Ho) di tolak dan Ha diterima. Maka dapat di simpulkan bahwa terdapat hubungan kuat dan siginifikan antara variabel pengetahuan dan minat.

Menurut hasil pengamatan yang peneliti lakukan maka, minat menabung santri dipengaruhi oleh pengetahuan yang sebelumnya telah dimiliki oleh santri tentang perbankan syariah. Didalam pondok pesantren Al-ittihad Mojokerto santri diajarkan tentang ekonomi Islam, melalui kegiatan mengaji kitab Al-Bulughul Maram, kitab ini membahas tentang syarat-syarat jual beli, hal-hal yang dilarang dalam jual beli, riba, pinjam-meminjam, Rahn, dan lain sebagainya. Selain itu, salah satu putra dari pengasuh pondok pesantren ini adalah pimpinan cabang salah satu bank syariah yang ada di Indonesia, sehingga ketika mengaji beliau sedikit banyak menyampaikan tentang perbankan syariah.

Berdasarkan pengamatan yang peneliti lakukakan pengetahuan yang dimiliki santri pondok pesantren Al-Ittihad Mojokerto tentang perbankan syariah diperoleh dari berbagai macam faktor di antaranya yaitu mereka mengetahui bahwa terdapat dewan pengawas syariah (DPS) sehingga mereka percaya bahwa bank syariah hanya bersedia membiayai investasi yang halal, memahami tentang sistem yang digunakan oleh perbankan syariah yaitu sistem bebas bunga dan menggunakan sistem bagi hasil. Sebagian besar santri telah mengaplikasikan dengan menabung di bank syariah. Minat

202 Vol. 4, No. 2, September 2019 
menabung santri sebagian besar berasal dari dalam diri mereka sendiri, karena ingin menghindari adanya riba atau sistem bunga yang terdapat pada bank konvensional, dan karena ingin melakukan transaksi dengan menggunakan syariat Islam, dan karena kemudahan prosedur dan administrasinya jika dibandingkan dengan bank konvensional, serta kenyamanan dalam bertransaksi di bank syariah. Selain itu, minat menabung santri juga dipengaruhi oleh faktor sosial, yaitu karena orang-orang disekitarnya seperti teman, ataupun saudara telah menggunakan bank syariah sehingga ia juga tertarik untuk bertransaksi dengan menggunakan bank syariah. Ada pula santri yang berminat menabung di bank syariah hanya karena faktor emosional atau keinginan sesaat dan hanya ingin mendapatkan keuntungan saja.

\section{Penutup}

Berdasarkan hasil penelitian dan pembahasan pengaruh pengetahuan santri tentang perbankan syariah terhadap minat menabung di bank syariah maka dapat disimpulkan bahwa terdapat pengaruh kuat dan siginifikan antara variabel pengetahuan santri $(\mathrm{X})$ dan variabel minat menabung $(\mathrm{Y})$. hal ini dapat diketahui dari nilai signifikansi variabel pengetahuan santri yaitu sebesar 0,000 atau lebih kecil dari 0,05 dan terdapat pengaruh yang positif antara variabel pengetahuan santri tentang perbankan syariah $(X)$ terhadap 
minat menabung di bank syariah $(\mathrm{Y})$. Dari hasil uji korelasi 2 variabel yaitu variabel pengetahuan santri $(\mathrm{X})$ dan variabel minat menabung $(\mathrm{Y})$ diperoleh nilai sebesar 0,753 , menurut kerentangan hubungan menunjukkan bahwa adanya hubungan yang kuat antara 2 variabel yaitu variabel pengetahuan santri $(\mathrm{X})$ dan variabel minat menabung $(\mathrm{Y})$. Berdasarkan kriteria kerentangan hubungan antara variabel dependen dan independen menunjukkan korelasi yang kuat dan signifikan antara variabel pengetahuan santri dan minat menabung. Dengan demikian, semakin besar pengetahuan maka semakin besar pula minat menabung. Diharapkan untuk penelitian selanjutnya, agar menambah jumlah responden dan variabel, agar hasil penelitian selanjutnya dapat dijabarkan lebih luas lagi.

\section{Daftar Pustaka}

Aditya Abdi, "Pengarub Pengetabuan tentang Perbankan Syariab terbadap Minat Menjadi Nasabah pada PT Bank. Mandiri Syariah Mandiri Tbk, Cabang Bondowoso", (Skripsi Fakultas Ekonomi dan Bisnis Universitas Negri Jember, Jember 2014).

Aini, Arifatul. Pengarub Pengetabuan Masyarakat Terbadap Minat Menjadi Nasabah Bank. Muamalat Cabang Kendal (Studi Pada Masyarakat Kecamatan Kota Kendal, Kabupaten Kendal). (Skripsi 
Fakultas Ekonomi dan Bisnis Universitas Islam Negri Walisongo, Semarang 2014).

Ascarya. 2007. Akad dan Produk Bank Syariah. Jakarta: Gramedia.

Danupranata, Gita. 2013. Manajemen Perbankan Syariah. Jakarta:

Salemba Empat.

Faras, Raifana. Pengarub Pengetabuan Tentang Riba Terbadap Minat Mahasiswa Universitas Islam Indonesia Untuk. Menjadi Nasabah Di Bank Syariah. (Skripsi Fakultas Ekonomi Universitas Islam Indonesia, Yogyakarta 2014).

Indarti, Nurul. 2014.Manajemen Pengetahuan: Teori dan Praktik. Yogyakarta: Gadjah Mada University Press.

Kamus Besar Bahasa Indonesia. 1990. Jakarta: Balai Pustaka.

Mapiare, Andi. 1982. Psikologi Remaja. Surabaya: Usaha Nasional.

Prasetyo, Bambang \& Jannah, Lina Miftahul 2006. Metode Penelitian Kuantitatif, Teori dan Aplikasi. Jakarta: PT Raja Grafindo Persada.

Saputra, Hendrik. 2019. 'Pengarub Persepsi Mahasiswa Program Studi Non Ekonomi Islam tehadap Minat menjadi Nasabah di Bank Syariah". Vol. 2, No. 1. 67-76

Shadily, Hasan. 1983. Ensiklopedia Umum. Jakarta: Ichtia Barn van hoeve.

Sukamto. 1985. Nafsiologi, Jakarta: Integritas Press.

Tim Redaksi. 2008. Kamus Besar Bahasa Indonesia Pusat Bahasa. Ed. 4. Jakarta: PT. Gramedia Pustaka Utama. 
Usman, Rachmadi. 2001. Aspek-Aspek Hukum Perbankan di Indonesia. Jakarta: Gramedia.

Wawan, Dewi. 2011. Teori dan Pengukuran Pengetahuan, Sikap, dan Perilaku Manusia. Yogyakarta: Nusa Medika.

Wirartha, I Made. 2006. Metodologi Penelitian Sosial Ekonomi. Yogyakarta: ANDI.

www.OJK.go.id di akses pada 16 Februari 2019, pkl. 08.42 